December 2005

IMF Country Report No. 05/435

\title{
Serbia and Montenegro: Report on the Observance of Standards and Codes- FATF Recommendations for Anti-Money Laundering and Combating the Financing of Terrorism
}

This Report on the Observance of Standards and Codes on the FATF Recommendations for Anti-Money Laundering and Combating the Financing of Terrorism for Serbia and Montenegro was prepared by the Council of Europe Select Committee of Experts on the Evaluation of Anti-Money Laundering Measures (MONEYVAL), using the assessment methodology adopted by the Financial Action Task Force in October 2002 and endorsed by the Executive Board of the IMF in November 2002. The views expressed in this document are those of MONEYVAL and do not necessarily reflect the views of the governments of Serbia and Montenegro or the Executive Board of the IMF.

To assist the IMF in evaluating the publication policy, reader comments are invited and may be sent by e-mail to publicationpolicy@imf.org. 



\title{
EUROPEAN COMMITTEE ON CRIME PROBLEMS (CDPC)
}

\section{SELECT COMMITTEE OF EXPERTS ON THE EVALUATION OF ANTI-MONEY LAUNDERING MEASURES (MONEYVAL)}

\author{
REPORT ON SERBIA AND MONTENEGRO \\ ON THE STANDARDS FOR ANTI-MONEY LAUNDERING AND \\ COUNTERING TERRORIST FINANCING
}




\section{A. Introduction}

1. This Report on the Observance of Standards and Codes (ROSC) for the FATF Recommendations for Anti-Money Laundering and 8 Special Recommendations for Combating the Financing of Terrorism (FATF 40+8 Recommendations) was prepared by the MONEYVAL Secretariat on the basis of the Detailed Assessment report $^{1}$ on Serbia and Montenegro, which was adopted at the Plenary meeting of the MONEYVAL Committee in Strasbourg, 21 January 2005. The report summarises the level of observance of the FATF 40+8 Recommendations and provides recommendations to enhance observance.

\section{B. Information and Methodology used for the Assessment}

2. This assessment is based on a review of the AML/CFT legislation and regulations of Serbia and Montenegro. Furthermore, the evaluators received from the Serbian and Montenegrin authorities information on the capacity and implementation of criminal law enforcement systems, and on supervisory and regulatory systems to deter money laundering and terrorist financing. The assessment team held discussions with officials and technical experts from a number of Serbian and Montenegrin departments and agencies, as well as representatives from the private sector. The assessment is based on the information available at the time of the onsite visits in Podgorica and Belgrade from 27 October to 2 November 2003.

3. Serbia and Montenegro is a state union consisting of two republics, the Republic of Serbia and the Republic of Montenegro. Each republic has separate government and parliament. However, there is also a parliament on the federal level.

4. When it comes to the Criminal Procedure Code and the Criminal Code, the situation is the following: Until 1991 Yugoslavia had one single Criminal Procedure Code (from 1977) applicable to the whole territory of the federation. A federal Criminal Code was enacted in 1976 regulating the general principles and a limited number of offences, while each republic held jurisdiction and issued legislation (Serbia in 1994 and Montenegro in 1993) over all other offences. In 2001 the federal assembly passed a new Criminal Procedure Code superseding the one from 1977. However, this Code did not apply to Montenegro, because a parliamentary resolution adopted by the Parliament of Montenegro denied legal effect to any text enacted by the Federal Assembly. Therefore, the 1977 Criminal Procedure Code was still enforceable with respect to Montenegro. With the entry into force of a Constitutional Charter, the power to legislate on criminal policy and procedure has been transferred entirely to each republic, and at the time of the on-site evaluation visit new Criminal Codes and Criminal Procedure Codes were being drafted both in Serbia and Montenegro.

5. All financial legislation is at republic level. For most areas of work the two republics do not share public institutions. Against this background it has been

\footnotetext{
${ }^{1}$ The detailed assessment was prepared by the MONEYVAL Secretariat based on contribution from an evaluation team which consisted of Mr. Doru Bulata, Romania; Mr. Lajos Korona, Hungary; Mr. Viesturs Burkans, Latvia; Mr. Charles Ott, USA; Mr. Giovanni Lupi, Italy, and a member of the MONEYVAL Secretariat.
} 
found the most appropriate in the following to describe the findings separately for respectively Serbia and Montenegro.

\section{Main findings}

\section{a. Serbia}

6. The AML/CFT regime of Serbia still lacks some essential components. On the repressive side there is not a specific provision on the financing of terrorism.It is possible to confiscate the proceeds of crime, but it is not possible to confiscate money intended to finance an act of terrorism. When it comes to seizure, only "objects" are covered by the legislation, thus it is not possible to seize the proceeds of crime just like it is not possible to seize bank accounts. Equally it is not possible to seize money intended to finance terrorism. The UN Security Council resolutions on the freezing of terrorism related assets have not been implemented by a specific normative act. All in all, the framework on confiscation and provisional measures is very weak. On the positive side it has to be noted, that the Serbian FIU is well-established and has a very dedicated staff. Furthermore, the preventive framework would seem to function. The customer identification requirements generally are adequate and so are the rules on internal control, integrity standards and enforcement powers and sanctions. As for the suspicious transaction reporting, there is no obligation to report a suspicion of financing of terrorism.

\section{(i) Criminal Justice Measures and International Co-operation}

\section{Criminalisation of Money Laundering and Financing of Terrorism}

7. Signature and ratification of treaties and conventions remained at union level. Furthermore, to ensure the continuity in interstate relations, both Serbia and Montenegro recognise the treaties previously concluded by the Federal Republic of Yugoslavia (FRY) and the Socialist Federal Republic of Yugoslavia (SFRY) without subsequent approval, even in cases where the implementation of the given treaty now belongs to the competence of republic level bodies.

8. The UN 1988 Convention Against Illicit Traffic in Narcotic Drugs and Psychotropic Substances (Vienna Convention) was ratified in 1990. The UN 1999 International Convention for the Suppression of the Financing of Terrorism was signed in November 2001 and ratified in October 2002. The UN 2000 Convention Against Transnational Organised Crime (Palermo Convention) and its supplementary protocols were signed in December 2000 and ratified in September 2001. The Council of Europe 1990 Convention on Laundering, Search, Seizure and Confiscation of the Proceeds from Crime 1990 (Strasbourg Convention) was signed and ratified in 2002 .

9. Money laundering is criminalised under article 27 of the Money Laundering Act. It covers "They who ... deposit money (cash, foreign currency in cash and other financial assets) acquired through illegal activity (grey economy, illicit traffic in arms, narcotic drugs and psychotropic substances and the like) into the accounts held with banks and other financial organisations and institutions ... or introduce 
in any other way such money (for which they knew it was acquired by criminal act) into legal financial flows with the aim to carry out permissible economic and financial activities" and carries a maximum penalty of 8 years of imprisonment. There is no specific provision on terrorist financing in Serbian legislation. As a consequence, for the criminalisation of terrorist financing, Serbia is relying on a combination of the provisions on terrorism (article 125 and article 155 a of the FRY 1976 Criminal Code on respectively domestic and international terrorism) and the generic provisions on aiding and abetting in the articles 22-26 of the Criminal Code. In the light of this, the evaluators recommend that Serbia, as a matter of priority, adopts a specific provision on terrorist financing.

\section{Confiscation of Proceeds of Crime or Property used to Finance Terrorism}

10. Confiscation is available for all criminal offences. As for the general regime, it clearly covers the proceeds deriving from crime and objects used or destined to be used in a criminal offence. This range of applicability is appreciated by the evaluators and so is the fact that the confiscation of proceeds is mandatory according to article 84-85 of the FRY Criminal Code. Nonetheless, the evaluators are not convinced that the current legal basis provides for the possibility of confiscating money, which is intended to finance terrorism. Article 69 of the FRY 1976 Criminal Code provides clearly for the confiscation of "objects" destined for use in a criminal action, but a normal interpretation of the concept of "objects" would not include money. This is seriously concerning the evaluators.

11. The rules on seizure cover only "objects" and consequently do not cover proceeds of an intangible nature, e.g. proceeds in the form of cash or the deposit on a bank account. The UN Security Council resolutions no. 1267, 1269 and 1373 relating to the prevention and suppression of the financing of terrorist acts have not been implemented by a specific normative act. The current legislation on seizure leaves no possibilities for the authorities to seize money which is intended to be used for an act of terrorism. It goes without saying that this is a critical situation.

The FIU and processes for receiving, analysing and disseminating intelligence at the domestic and international levels

12. The Serbian FIU became member of the Egmont Group in 2003 and thus meets the Egmont Group criteria. In general, the Serbian FIU leaves a positive impression as an agency, which is very pro-active and is gradually becoming the centre and the leading force of the Serbian anti-money laundering system. The work done concerning the establishment of a reporting system and of the FIU thus merits a positive evaluation. Also the co-operation with other domestic agencies is working out relatively well, both when it comes to receiving suspicious transactions reports and when it comes to the legal possibilities for the FIU to provide law enforcement regime with information related to money laundering.

\section{Law enforcement and prosecution authorities, powers and duties}

13. The Serbian Police are under the responsibility of the Ministry of Interior. In the Department for Combating Organsied Crime is the Division for Combating Organised Financial Crime. The evaluators were informed by the Serbian 
interlocutors that the Division for Combating Organised Financial Crime is going to be reorganised, and will be divided into 3 sections one of which will be dealing with the investigation of money laundering cases $^{2}$. The evaluators were told that the money laundering section will consist of 12-13 staff members. Furthermore, the evaluators were informed; that in another of the divisions a new section responsible for the investigation of cases related to terrorist financing will be created.

14. Controlled delivery can be carried out only upon the approval of a prosecutor, and only in cases of very serious crimes (including money laundering, corruption, drug crimes and kidnapping). It is possible for the police to get bank account information two different ways. One way is via the FIU, but this is only possible where the FIU has transferred a money laundering case to the police (i.e. based on a suspicious transaction report). Another way is via the public prosecutor.

15. The Serbian law enforcement system still finds itself in the stage of development. However, confidence in respect of the system is boosted by the fact that the chosen direction of development in many respects seems to be right. The Criminal Police would seem to have the necessary investigative tools. However, a formal legal basis for the use of controlled deliveries is recommended by the evaluators. When it comes to real money laundering cases, there is a total lack of convictions. Apparently there is still a tendency to focus only on the predicate crime rather than also including the laundering offence. Therefore, the Police should enhance the focus on the tracing and detecting of assets. In line with this, Serbia is recommended to extend the possibilities for the police and the public prosecutors to get access to bank account information.

\section{International Co-operation}

16. In Serbia the requested legal assistance can be carried out if the same process could be exercised in a similar domestic case, i.e. the dual criminality principle is being applied. This, however, might limit the possible range of the applicable measures because of the restrictive nature of provisional measures from the angle of seizing or freezing of bank accounts and proceeds of an intangible nature in general $^{3}$. This of course has implications for legal assistance, because requests from abroad for such security measures cannot be exercised to a wider extent in international co-operation than in domestic cases.

17. Considering the conditions of extradition as defined by article 540 of the Criminal Procedure Code, the applicability of this measure is notably restricted. On the other hand, article 536 dealing with the transfer of proceedings is of a rather discretionary nature. As a consequence, it is to be feared that these two options together could not provide for a perfect coverage, thus, there might be situations in which neither of them could be met.

\footnotetext{
${ }^{2}$ Subsequent to the evaluation visit the evaluators were informed by the Serbian authorities that the reorganisation has been carried out as planned.

${ }^{3}$ Because it is possible to seize only "objects".
} 


\section{(ii) Preventive measures for Financial Institutions}

\section{Prudentially regulated sectors}

\section{General framework}

18. The secrecy rules do not represent an obstacle for the FIU to implement the provisions of the law, to co-operate with law enforcement and regulatory authorities and to exchange information with foreign FIU's. Furthermore, the FIU can, after having received a suspicious transaction report, ask the reporting party and other parties involved in the transaction for additional information.

19. The evaluation team was impressed with the undoubted serious commitment of Serbian FIU staff in countering money laundering. The FIU is also actively involved in improving the reporting system through training seminars and good contacts have been developed with the managers and compliance officers in the bank which the evaluators visited.

\section{Customer Identification}

20. There is no explicit prohibition in the laws on opening of anonymous account. All the obligated entities under the Money Laundering Act are required, according to article 6 of the Money Laundering Act, to identify their clients when establishing business relations.

21. The evaluators recommended that the banks put into place graduated customer acceptance policies and procedures that require more extensive due diligence for higher risk customer. It is recommended for the banks to apply enhanced diligence procedures towards a customer, if there is any reason to believe that the customer is being refused banking facilities by another bank. It is moreover recommended to develop specific policies and procedures for handling banking relations with politically exposed persons. It is also recommended for the banks to have policies and procedures regarding the opening of correspondent accounts.

22. The representatives of the Central Bank informed the evaluators that numbered accounts are permitted but this type of accounts represents a very small part of the total amount of opened accounts. These accounts may be opened for the already identified account holders in view of ensuring a high level of confidence. It is the opinion of the evaluators that the existence of numbered accounts may constitute a potential money laundering risk. The evaluation team therefore recommends the Serbian authorities so satisfy themselves that the holder of numbered accounts can be identified and thus to make sure that this kind of accounts is not posing a money laundering risk.

\section{On-going monitoring of accounts and transactions}

23. Specific rules on monitoring of accounts and transactions do not exist. However, if a transaction is suspicious, a report should be send to the FIU in accordance with the reporting obligation of the Money Laundering Act. 
24. The evaluation team recommends the banking industry to introduce as soon as possible systems to aggregate and monitor significant balances and activity in customer accounts on a fully consolidated basis and conduct intensified monitoring for higher risk accounts. It is also recommended to put in place obligations concerning ongoing monitoring of transactions also in the non-banking financial sectors, where currently no obligations, and seemingly no practices, are in place.

\section{Record-keeping}

25. The obligated entities are required to keep records on customer identity, as well as other documentation related to the conducted transaction, at least five years after conducting the transaction. However, the period of time to keep the information related to the identity of a client is not spelled out explicitly, since article 25 only provides that the information should be stored until 5 years after the transaction. Therefore, it is recommended a clear provision to be adopted concerning the keeping of identification information. It is recommended to keep the records for at least 5 years after the termination of the business relations with the client.

\section{Suspicious transactions reporting}

26. The obligated parties shall inform the FIU of any suspicions of money laundering. It is the task of the compliance officer to take the decision to report. Apart from suspicious transaction reports, the obligated parties must also submit cash transaction report to the FIU. The cash reporting obligation follow the same line as the identification requirements for large stand alone transactions, i.e. a cash report must be send where the transaction exceeds YUD 600.000 as well as single insurance premiums exceeding 40.000 .

27. The evaluation team recommends Serbia to provide directly in the Money Laundering Act a system of mandatory reporting of suspicious transactions concerning financing of terrorism. It is also recommended to introduce a provision on the prohibition of tipping-off the clients that a report has been sent to the FIU.

\section{Internal control, compliance and audit}

28. The control procedures and staff training are formally in place. Internal audit of the programmes of reporting entities is also catered in the legal structure, which represents a good point. Though the rules on money laundering would seem to be fairly satisfactory, there are no reference anywhere to the prevention of the financing of terrorism. The evaluators also recommend financial institutions to take into consideration adopting adequate screening procedures to ensure high standards when hiring employees.

\section{Integrity standards}

29. The Central Bank of Serbia can revoke a banking license when it is established that the data and information regarding the founders are false or the activity of the bank is not in compliance with the law. It is the impression of the evaluators that Central Bank pays a special attention to the risks of criminal infiltration in the 
banking system. The procedure for prior approval of large shareholders is also a step in the right direction.

30. The evaluators recommend Serbia to reconsider whether the integrity standards generally are satisfactory in the insurance and securities sectors. Furthermore, the evaluation team recommend a more effective co-operation between supervisory authorities in the area of monitoring the integrity of large investors and managers in financial entities. The Serbian authorities should satisfy themselves, that the potential misuse of non-profit organisations should be dealt with. As a minimum such organisation should be registered and thus made know to the authorities.

\section{Enforcement powers and sanctions}

31. Articles 63-65 of the Law of the Central Bank give the authority to the Central Bank to conduct different enforcement actions. It is stated that the supervisors of the Central Bank are authorised to check compliance of all banking procedures and all documents concerning accounts and transactions. It is also stated that the Central Bank should co-operate with foreign and domestic institutions responsible for supervision in the field of financial transaction. The Ministry of Finance as insurance supervisor can enforce sanctions against the supervised entities if they do not comply with the legislation. According to the Law on Insurance the Ministry of Finance has the right to ask the supervised company to remedy the situation (article 130). If this is not sufficient the operations of the company can be limited or the licence withdrawn. The Security Commission is entitled to ask for any document during on-site inspections, off-site monitoring and within licensing procedures and following changes in the ownership and/ or managerial changes. In case the legal stipulations are violated either a corrective action, a fine or a revocation of license or professional qualification can be applied.

32. The enforcement powers of Central Bank seem to be quite appropriate and have been applied in practice by the revocation of the licenses for one commercial banks. Regarding the insurance and securities sectors, the different enforcement tools available for the supervisory authorities seem on paper to be quite appropriate. However, the effectiveness in practice is difficult to assess, since the enforcement powers and sanctions have been applied in those sectors.

\section{Co-operation between supervisors and other competent authorities}

33. Article 23 of the Money Laundering Act empowers the Serbian FIU to conclude agreements on data, information and documentation exchange with relevant bodies of foreign countries or international organisations. Article 65 of Law on Central Bank states that the Central Bank should co-operate with foreign institutions responsible for banking supervision, domestic bodies and supervising institutions in field of financial transactions.

34. All financial supervisory bodies seem to be adequately equipped with human and technical resource to carry out the primary tasks as prudential supervisors. However, in the specific AML/CFT field only the FIU and the Central Bank seem to have the necessary expertise whereas the supervisory for the insurance and securities sectors still have a long way to go before a satisfactory level is reached. 
The practical co-operation between the financial supervisory authorities is of some concern to the evaluators, since it appears to be very limited and only on case by case basis.

Non-prudentially regulated sectors

35. The Serbian Money Laundering Act applies not only to the financial sector, but also to a number of other sectors, including: Post offices, persons engaged in the buying and selling of precious metals and jewellery, exchange offices, pawnshops, gambling rooms, betting places, slot machine clubs, lotteries, real estate agents as well as traders in arts and antiques.

36. However, still a few relevant businesses seem not to be included in the AML framework. Of particular relevance are money remitters but also accountants, auditors and lawyers should be included in the Money Laundering Act.

\section{b. Montenegro}

37. Also the AML/CFT regime of Montenegro still lacks essential components. At the time of the on-site visit still no Montenegrin FIU had been established ${ }^{4}$. It goes almost without saying, that this was of concern, because an FIU was very much needed to co-ordinate the AML/CFT efforts. On the repressive side there is not a specific provision on the financing of terrorism. It is possible to confiscate the proceeds of crime, but it is not possible to confiscate money intended to finance an act of terrorism. It is not possible to seize the proceeds of crime just like it is not possible to seize bank accounts. Equally it is not possible to seize money intended to finance terrorism. The UN Security Council resolutions on the freezing of terrorism related assets have not been implemented by a specific normative act. All in all, the framework on confiscation and provisional measures is very weak. On the positive side it has to be noted that the preventive framework would seem to function, at least on paper. The customer identification requirements generally are adequate and so are the rules on internal control, integrity standards and enforcement powers and sanctions. The requirements for record-keeping go beyond the internationally required standard since the Money Laundering Act requires the keeping of records for a period of 10 years. As for the suspicious transaction reporting, there is no obligation to report a suspicion of financing of terrorism.

\section{(i) Criminal Justice Measures and International Co-operation}

\section{Criminalisation of Money Laundering and Financing of Terrorism}

38. As mentioned above, signature and ratification of treaties and conventions remained at union level. Therefore, the description on Serbia regarding the status of signature and ratification of various international instrument in the field of AML/CFT, also applies to Montenegro.

\footnotetext{
${ }^{4}$ Subsequent to the on-site visit the evaluators were informed by the Montenegrin authorities that the FIU has been established and that it was operational as of 20/11 2003.
} 
39. In Montenegro, money laundering is criminalised under article $129 \mathrm{a}^{5}$ of the Criminal Code. It covers "Anyone who, during banking, currency or other economic activities invests, undertakes, changes or in other way hides the real source of money, or objects or rights gained with money known to be obtained by a criminal act", and carries a maximum penalty of 12 years of imprisonment. The financing of terrorism is not criminalised by a specific article of neither of the Criminal Codes. However, according to the Montenegrin authorities, article 125 and article 155 a (on respectively domestic and international terrorism) combined with the generic provisions on aiding and abetting in the articles 22-26 of the Criminal Code, would make it possible to sanction the financing of terrorism. In the light of this, the evaluators recommend that Montenegro, as a matter of priority, adopts a specific provision on terrorist financing.

\section{Confiscation of Proceeds of Crime or Property used to Finance Terrorism}

40. The FRY 1976 Criminal Code applies both to Serbia and to Montenegro. Article 84 and 85 are general provisions, thus applicable to money laundering as well. There is, however, a separate money laundering confiscation provision in article 129 a, paragraph 6, of the 1993 Montenegrin Criminal Code (as amended) stating that "money and property referred to in para. 1, 2 and 3 of this article shall be taken away". Both article 84-85 and article 129 a, paragraph 6, serve as foundation for confiscation of proceeds. There is no provision which explicitly allows the confiscation of money intended to finance terrorism.

41. There are no provisions in Montenegro on the seizure of proceeds from crime, just like it is not possible to seize money intended to finance terrorism. The provisions on seizure would cover only objects intended to be used as proof in court. Consequently, it is not possible to seize bank accounts. As far as the execution of the United Nations resolutions relating to the prevention and suppression of the financing of terrorism is concerned, no special powers were given to the authorities with regard to the implementation of these resolutions.

42. As a top priority the Montenegrin authorities should make sure, that it is possible to confiscate money intended to be used for acts of terrorism. In this respect, it is recommended to include in the new Montenegrin Criminal Code a provision carrying the elements of the current article 69 of the FRY Criminal Code but extended also to apply to money and/or the substitutes of money (not just "objects"). When it comes to seizure and freezing an entirely new framework is needed. Currently this area is almost unregulated. As a minimum should be urgently put in place complete provisions making it possible not only to seize evidence, but also proceeds (with the wide meaning given in the Strasbourg Convention) and objects and assets (including money) intended to be used in an act of terrorism. Furthermore, the authorities should be give the possibilities to freeze without delay the assets of person and/or organisation designated by the UN Security Council resolutions.

\footnotetext{
${ }^{5}$ Subsequent to the evaluation visit the evaluators were informed by the Montenegrin authorities that the money laundering offence now is in article 268 of the Montenegrin Criminal Code.
} 
The FIU and processes for receiving, analysing and disseminating intelligence at the domestic and international levels

43. At the time of the on-site evaluation visit in Montenegro, there was no Financial Intelligence Unit. It should be noted that the Central Bank performs some FIU functions. However, the Central Bank is far from being regarded as an analogue to an FIU. The evaluators recommend the creation of an FIU and the adoption of its legal basis as a matter of the highest urgency. It is important to create an adequate structure with a sufficient number of skilled staff members and with sufficient technical and other means to successfully perform all their functions in full extent. The FIU should have legal and technical possibilities to retrieve information from databases, to request additional information and to forward the compiled data to the law enforcement authorities as well as foreign FIU's.

\section{Law enforcement and prosecution authorities, powers and duties}

44. The Montenegrin Police is organised within the Ministry of Interior. There is a Central Administration for the Suppression of Crime. The Central Administration consists of a number of Departments, including the Department for the Suppression of Organised Crime. This Department has a total staff of 8 persons and are split into 5 divisions: 1) Money Laundering (1 person only), 2) Cyber crime, 3) Serious Crimes (serious theft and other types of acquisitive offences), 4) Corruption and 5) Human Trafficking. There are no special structures for the investigation of terrorism or the financing thereof.

45. There is no normative basis in place for carrying out operative activities (e.g. controlled deliveries) and they have not been conducted in practice ${ }^{6}$. As for the access to bank account information, the police cannot get such an access. In some cases apparently the public prosecutor has asked the investigative judge for a production order, but the Montenegrin interlocutors did not point at a specific legal basis for this.

46. The role of the Customs Service is very modest when it comes to contributing to fighting economic crime. In fact, the Customs Service would not find itself having the competence of investigating money laundering where the predicate crime is a customs offence or a smuggling offence.

47. At the time of the on-site evaluation visit no money laundering cases had been initiated, neither by the police nor by the prosecutor's office. Regarding the police it is recommended to vest much more resources to the Money Laundering Division of the Organised Crime Department. It is quite simply impossible for one person to deal with the cases, particularly when the prospective FIU hopefully in a near future starts performing its duties. In general, the existing police structures, not least the Departments on Organised Crime and Economic Crime should carry out real financial investigations (tracing and identification of the proceeds from crime) at the same time as the criminal investigations. For the time being there is a total lack of focus on the proceeds from the crimes.

\footnotetext{
${ }^{6}$ Subsequent to the on-site visit the evaluators were informed by the Montenegrin authorities that the Criminal Procedure Code article 237, paragraph 5, now allows for controlled deliveries.
} 


\section{International Co-operation}

48. Like in Serbia, also Montenegro applies the dual criminality principle. This, however, is seriously limiting the range of the applicable measures, since in Montenegro there is no general provision on the seizure or freezing of proceeds from crime and since it is not possible to seize bank accounts. Failing statutory provision, or at least an existing court practice to the contrary, it appears that the principle of dual criminality is to be applied in money laundering cases as well, which might, considering the relatively restricted definition of the offence, limits the possibilities to assist.

49. Considering the conditions of extradition as defined by article 525 of the Criminal Procedure Code, the applicability of this measure is fairly restricted, thus it is to be feared that in many cases this option could not provide a perfect coverage. It would be useful if the authorities considered analysing whether the nonextradition of own nationals is being followed up by a proper submission of criminal proceedings from the foreign country to Montenegro and to ensure that this occurs.

\section{(ii) Preventive measures for Financial Institutions}

\section{Prudentially regulated sectors}

\section{General framework}

50. The Money Laundering Act provides in article 37 the general rule regarding confidentiality and secrecy regulations. When forwarding data, information and documentation to the FIU the obligation to protect bank secrecy, business and official secrecy is not applicable for reporting entities or public institutions. Furthermore, the professional secrecy can be lifted on the basis of a written order of the court during the investigations of the cases concerning money laundering and financing of terrorism.

51. The serious general impediment for an effective implementation of the FATF Recommendations and other international standards is the lack of a central authority to ensure the proper implementation of the law ${ }^{7}$. The evaluators recommended that Montenegro urgently sets up a body in charge of money laundering and terrorist financing. The body should fulfil the Egmont Group FIU standard.

\section{Customer Identification}

52. There is no explicit prohibition in the laws on opening of anonymous accounts or accounts in fictitious names. According to the Money Laundering Act the identification of clients is mandatory for all obligated parties in the following circumstances: When a an account is opened for a client or another kind of business relationship with a client is established; when a transaction exceeds euro

\footnotetext{
${ }^{7}$ See footnote no. 4 .
} 
15.000; when there is a suspicion of money laundering. For insurance companies and insurance intermediaries there are furthermore additional rules.

53. The issue of creating special policies and procedures for handling banking facilities with politically exposed persons has not been addressed in Montenegro. Equally, there are no direct provisions which require to keep customer identification information up to-date and relevant by undertaking regular reviews of existing records. It is recommended to adopt special procedures to deal with these topics in an adequate manner.

54. Representatives of the law enforcement authorities informed the evaluators that a considerable number of off shore banks are still functioning and performing significant financial transactions out of Montenegro via the Internet, but that the activities now are carried out illegally.

On-going monitoring of accounts and transactions

55. Specific rules on monitoring of accounts and transactions do not exist. However, according to Central Bank decision no. 45/02 the Montenegrin banks are obliged to pay special attention to transactions that are unusual. If the business transaction is larger than normal or unusual, authorised persons from the bank must require additional information and data on the origin of funds or assets from the client, in order to clarify the reason and purpose of that business relationship. There are no specific rules, which require financial institutions to pay special attention to wire transfers that do not contain complete originator information. It was not entirely clear whether there is a mechanism in place for disseminating FATF Recommendation 21 notices. Some guidance on unreliable jurisdiction would therefore be of assistance to the financial institutions.

\section{Record-keeping}

56. According to article 39 of the Money Laundering Act, all obligated entities must keep all necessary records on transactions and customer identification for 10 years after the last transaction has been performed or after the termination of the business relationship.

57. The evaluators recommend the supervisory agencies for the insurance and securities sectors to play more active roles in supervising the implementation of proper record keeping regime as well as to issue guidelines, policies and procedures to ensure the integrity, reliability and thoroughness of all the relevant stored information.

\section{Suspicious transactions reporting}

58. According to article 13 of the Money Laundering Act, the obligated entities must report to the FIU all cases where a transaction or client raises suspicion of money laundering. In case of a suspicious transaction report, the FIU may suspend the transaction for a maximum of 72 hours. 
59. There is also a system of cash reporting in Montenegro. All obligated parties shall - according to article 13, paragraph 1 of the Money Laundering Act - report to the FIU in case of transactions exceeding euro 15.000 and in case of inter-connected transactions exceeding the same amount.

60. There are no provisions regarding the obligations of the financial institutions to report their suspicions related to financing of terrorist activities. The lack of such system in Montenegro is crucial to the effectiveness of the entire framework against this type of crime and has an obvious impact on the possibilities for the law enforcement authorities to initiate investigations. Therefore, the evaluation team recommends that Montenegro authorities provide directly in primary legislation a clear obligation to report in case of a suspicion related to the financing of terrorism.

\section{Internal control, compliance and audit}

61. According to article 15 of Money Laundering Act, the obliged entities should establish a written compliance plan as a basis to develop policies, procedures and practices for identification of suspicious transactions, develop special compliance programs, including establishment of internal procedures and controls, helping all employees understand a list of indicators for identification of suspicious transactions and training for the staff. Article 15 also provides that the obliged entities should designate a compliance officer with special powers and responsibilities who is responsible to conduct anti-money laundering activities.

62. Financial institutions are not obliged to establish and maintain internal procedures to prevent them from being used for financing of terrorism purposes. The evaluation team recommends the issuing of a special legal basis to include components related to the internal control of counter terrorist financing procedures and training of staff.

63. It is positive to note that for banks sceening requirements for new staff exist. On the contrary the requirements are lacking for other sectors (or are not spelled out).

\section{Integrity standards}

64. According to article 20 of the Law on Banks, the Central Bank should revoke a banking license when it is established that, over a longer period of time, a bank has been involved in unsafe and unsound practices that endangered the safety of deposits.

65. The Central Bank Decision on procedures and manner of issuing banking licenses provides that the statements from the bank founders regarding the payment of the initial share capital must be given by each shareholder individually, must be dated and must bear the founder's signature, certified by a court of competent jurisdiction or an attorney. Generally, it is the view of the evaluators that Central Bank seems conscious of the risks of criminal infiltration of the banking system. This is also demonstrated by the fact that the entire management of the banks needs to have the Central Bank prior approval. Also for insurance and securities companies certain "screening procedures" are in place when approving the 
management. On the other hand, when it comes to the checking of the initial minimum capital, there is no control procedure being applied for the insurance sector.

66. No specific requirements are in place concerning the prevention of the potential misuse of non-profit organisations in relation to money laundering and financing of terrorism. It is recommended for the Montenegrin authorities to consider verifying adequately the activites of such organisations.

\section{Enforcement powers and sanctions}

67. According to article 44 of the Central Bank Law, the Central Bank has the power to sanction the banks or financial institutions at the discovery of infringements of banking regulations. The Central Bank can issue orders to the banks or financial institutions on how to eliminate the infringements.If the banks or financial institutions deny the Central Bank staff access to the business books and other documentation at the request of the Central Bank, the managers are subject to a fine.

68. It is necessary that all the existing supervisory authorities ensure that inspection of anti-money laundering and counter the financing of terrorism issues becomes part of their supervisory regimes and they have the powers to sanction. The evaluators recommend that the various existing supervisory bodies should now implement targeted inspections to ensure that subjects comply with the requirements of the Money Laundering Act. Currently no such inspections are in place.

\section{Co-operation between supervisors and other competent authorities}

69. According to article 5 of Central Bank Decision no. 45/02, the Central Bank should co-operate with domestic and foreign institutions on issues related to exchange of current data and information regarding detection and prevention of suspicious transactions. However, the evaluators were not provided with information concerning how the co-operation works in practice. The same applies to the insurance and securities sectors.

\section{Non-prudentially regulated sectors}

70. The Montenegrin Money Laundering Act applies not only to the financial sector, but also to a number of other sectors, including: Post offices, gambling houses and other organisers of games of chance, exchange offices, pawnshops, real estate agents, travel organisations, auction houses as well as traders in arts, boats and automobiles.

71. However, still a few relevant businesses seem not to be included in the AML framework. Of particular relevance are money remitters, which should be included in the Money Laundering Act ${ }^{8}$.

\footnotetext{
${ }^{8}$ Subsequent to the evaluation visit the Montenegrin authorities informed the evaluators that no money remitters operate in Montenegro.
} 


\section{Summary Assessment of the FATF Recommendations}

72. Both Serbia and Montenegro still have a considerable way to go before a sufficient level of compliance with the FATF $40+8$ Recommendations is reached. An immediate priority for both republics should be a thorough improvement of the provisions on provisional measures and confiscation. Furthermore, both republics also need to adopt specific provisions on the countering of financing of terrorism, both the criminalisation and the obligation to report in case of a suspicion of financing of terrorism. For Montenegro another immediate priority should be the making operational of a Financial Intelligence Unit. As mentioned, an FIU was established shortly after the on-site visit, but the evaluators have not been able to assess whether it is complying with the Egmont FIU standards.

73. Table 1 beneath summarises recommended actions in areas relating to the FATF $40+8$ Recommendations, and Table 2 contains other recommendations to further enhance the AML/CFT regime. 
Table 1. Recommended Action Plan to improve compliance with the FATF Recommendations

\begin{tabular}{|c|c|}
\hline Reference FATF Recommendation & Recommended Action \\
\hline \multicolumn{2}{|l|}{40 Recommendations for $\mathrm{AML}$} \\
\hline \multirow[t]{2}{*}{$\begin{array}{l}\text { Scope of the criminal offence of } \\
\text { money laundering (FATF 4-6) }\end{array}$} & $\begin{array}{l}\text { Both Serbia and Montenegro are } \\
\text { recommended: }\end{array}$ \\
\hline & $\begin{array}{l}\text { To redefine to scope of their respective } \\
\text { money laundering offence in order to make } \\
\text { sure that all the physical elements as required } \\
\text { by the Council of Europe } 1990 \text { Convention } \\
\text { are covered, including to conceal, acquire, } \\
\text { possess or use the proceeds from crime. In } \\
\text { Serbia, at the time of the on-site visit, a law } \\
\text { to cover those elements was being drafted. }\end{array}$ \\
\hline \multirow[t]{2}{*}{$\begin{array}{l}\text { Provisional measures and } \\
\text { confiscation (FATF 7) }\end{array}$} & $\begin{array}{l}\text { Both Serbia and Montenegro are } \\
\text { recommended: }\end{array}$ \\
\hline & $\begin{array}{l}\text { To adopt provisions making it possible to } \\
\text { seize and confiscate both proceeds, property } \\
\text { and instrumentalities. } \\
\text { To adopt provision making it possible to } \\
\text { seize and confiscate money intended to } \\
\text { finance terrorism. }\end{array}$ \\
\hline \multirow[t]{4}{*}{$\begin{array}{l}\text { Customer identification and record- } \\
\text { keeping rules (FATF 10-13) }\end{array}$} & $\begin{array}{l}\text { Both Serbia and Montenegro are } \\
\text { recommended: }\end{array}$ \\
\hline & $\begin{array}{l}\text { To adopt special requirements for the banks } \\
\text { to have in place graduated customer } \\
\text { acceptance policies and procedures that } \\
\text { require more extensive due diligence for } \\
\text { higher risk customers. } \\
\text { To adopt special requirements for banks to } \\
\text { apply enhanced diligence procedures to a } \\
\text { customer, if there are reasons to believe that } \\
\text { the customer is being refused by another } \\
\text { bank. } \\
\text { To create special policies and procedures for } \\
\text { handling banking facilities with politically } \\
\text { exposed persons. }\end{array}$ \\
\hline & Furthermore, Serbia is recommended: \\
\hline & $\begin{array}{l}\text { To adopt a provision which clearly defines } \\
\text { the period of time to keep the information } \\
\text { related to the identity of a client (article } 25 \text { of } \\
\text { the Money Laundering Act only provides that } \\
\text { the information should be stored until } 5 \text { years } \\
\text { after the transaction.) }\end{array}$ \\
\hline
\end{tabular}




\begin{tabular}{|c|c|}
\hline $\begin{array}{l}\text { Increased diligence of financial } \\
\text { institutions (FATF 14-19) }\end{array}$ & $\begin{array}{l}\text { Both Serbia and Montenegro are } \\
\text { recommended: } \\
\text { To adopt provisions for the performance of } \\
\text { on-going monitoring of accounts and } \\
\text { transactions }\end{array}$ \\
\hline $\begin{array}{l}\text { Measures to cope with countries with } \\
\text { insufficient AML measures (FATF } \\
\text { 20-21) }\end{array}$ & $\begin{array}{l}\text { Both Serbia and Montenegro are } \\
\text { recommended: } \\
\text { To consider on an up-dated basis providing } \\
\text { all relevant intermediaries with information } \\
\text { about which countries and jurisdictions } \\
\text { should be considered non-cooperative in an } \\
\text { AML/CFT context. }\end{array}$ \\
\hline $\begin{array}{l}\text { Administrative Co-operation - } \\
\text { Exchange of information relating to } \\
\text { suspicious transactions (FATF 32) }\end{array}$ & $\begin{array}{l}\text { Montenegro is recommended: } \\
\text { To adopt an STR regime making it possible } \\
\text { internationally to exchange information } \\
\text { relating to suspicious transaction, persons and } \\
\text { corporations. }\end{array}$ \\
\hline $\begin{array}{l}8 \text { Special Recommendations on } \\
\text { terrorist financing }\end{array}$ & \\
\hline $\begin{array}{l}\text { Criminalising the financing of } \\
\text { terrorism and associated offences } \\
\text { (FATF SR II) }\end{array}$ & $\begin{array}{l}\text { Both Serbia and Montenegro are } \\
\text { recommended: } \\
\text { To adopt a separate offence on terrorist } \\
\text { financing. }\end{array}$ \\
\hline $\begin{array}{l}\text { Freezing and confiscating terrorist } \\
\text { assets (FATF SR III) }\end{array}$ & $\begin{array}{l}\text { Both Serbia and Montenegro are } \\
\text { recommended: } \\
\text { To adopt a comprehensive normative act } \\
\text { providing a mechanism to implement the } \\
\text { freezing without delay of assets suspected to } \\
\text { be related to the financing of terrorism. }\end{array}$ \\
\hline $\begin{array}{l}\text { Reporting suspicious transactions } \\
\text { related to terrorism (FATF SR IV) }\end{array}$ & $\begin{array}{l}\text { Both Serbia and Montenegro are } \\
\text { recommended: } \\
\text { To adopt for all relevant intermediaries a } \\
\text { mandatory reporting regime on suspicious } \\
\text { transactions and activities related to the } \\
\text { financing of terrorism. }\end{array}$ \\
\hline $\begin{array}{l}\text { Alternative remittance (FATF SR } \\
\text { VI) }\end{array}$ & $\begin{array}{l}\text { Both Serbia and Montenegro are } \\
\text { recommended: } \\
\text { To have all alternative remitters comprised } \\
\text { by the Money Laundering Act, and thus } \\
\text { oblige them to comply with the requirements } \\
\text { regarding customer identification, record- } \\
\text { keeping, suspicious transaction reporting etc. }\end{array}$ \\
\hline
\end{tabular}


Table 2. Other Recommended Actions

\begin{tabular}{|l|l|}
\hline Reference & Recommended Action \\
\hline Law Enforcement and Prosecution & $\begin{array}{l}\text { Both Serbia and Montenegro are } \\
\text { recommended: }\end{array}$ \\
$\begin{array}{l}\text { To adopt a comprehensive training strategy } \\
\text { for the agencies involved in AML/CFT issues } \\
\text { should be embarked upon. } \\
\text { To introduce a further use of investigative } \\
\text { means, including special investigative } \\
\text { techniques, such as controlled deliveries. } \\
\text { To see to that all relevant law enforcement } \\
\text { authorities and the Office of the Prosecutor } \\
\text { General address the issue of the importance } \\
\text { of financial investigations. }\end{array}$ \\
$\begin{array}{l}\text { Furthermore, Montenegro is recommended: } \\
\text { To set up and make operational a Financial } \\
\text { Intelligence Unit. The FIU should be properly } \\
\text { resourced and should be able to exchange } \\
\text { relevant information with national law } \\
\text { enforcement authorities as well as foreign } \\
\text { counterparts. } \\
\text { To see to that the role of the Customs Service } \\
\text { in relation to AML/CFT issues is enhanced. }\end{array}$ \\
\hline
\end{tabular}

